\title{
Some Common Non-Timber Forest Products Traded by Indigenous Community in Sabah, Malaysia
}

\author{
Julius Kodoh \\ School of International Tropical Forestry \\ Universiti Malaysia Sabah \\ Locked Bag 2073, Kota Kinabalu 88999 Sabah, Malaysia \\ Tel: 6-088-320-000Ｅ-mail: Julius@ums.edu.my \\ Andy Russel Mojiol (Corresponding author) \\ School of International Tropical Forestry \\ Universiti Malaysia Sabah \\ Locked Bag 2073, Kota Kinabalu 88999 Sabah, Malaysia \\ Tel: 6-088-320-118Ｅ-mail: rmojiol@yahoo.co.uk \\ Walter Lintangah \\ School of International Tropical Forestry \\ Universiti Malaysia Sabah \\ Locked Bag 2073, Kota Kinabalu 88999 Sabah, Malaysia \\ Tel: 6-088-320-000 E-mail: walterj1@ums.edu.my
}

\begin{abstract}
The survey showed that a total number of 109 species of NTFPs were traded locally in the tamu (open market), comprising 35 species of wild edible plants, 32 species of medicinal plants, 8 species of orchids, 4 species of bamboos, 6 species of rattans, 8 species of fish, 8 species of wild fruit trees and 8 species of other products. This survey covered ten most common tamu and major ethnic groups in Sabah, mainly Kadazandusun, Rungus and Murut.
\end{abstract}

Keywords: Traded Non-Timber Forest Products, Tamu (open market), Indigenous community, Sabah

\section{Introduction}

Non-Timber Forest Products (NTFPs) play a major role in the lives of more than 30 million forest dependent people in Southeast Asia (de Beer \& McDermott 1989). The situation is similar throughout the tropics, where people utilize NTFPs within the household and trade them for money and other products locally or in the region (Tiwari 1994). For many years, non-timber species such aromatic and medicinal plants, bamboo, rattan, fruits, nuts, resins, gums and mushrooms played important roles in the socio-economic development of Malaysia (Azizol \& Appanah 1998).

Many of the NTFPs have provided useful and important products for the local people of the state of Sabah. There are about 84 species of rattans found in Sabah (Dransfield 1984). Sabah has at least seven genera of bamboos with an approximately thirty four species (Kulip 1992). There are more than 100 species used as medicinal plants to treat 34 ailments in the west coast and interior of Sabah. The main sources of medicinal plants in Sabah are from plants growing wild in the primary or secondary forests. Some commonly used plants are planted around houses (Kulip 1997). Lee \& Gibot (1986) have reported on more than 200 species of native edible plants found in Sabah. Whilst, Wong (1992) reported that Sabah's tropical is home to about 155 species of freshwater fish and 1500 species of orchids. 
The term NTFPs used in this study include all forest goods, except timber and the forest services. They are tangible objects of biological origin such as plants, animals and their products derived from the forest that traded in the tamu. Тати or "Open Market" is a place where most of indigenous traders gather to buy, sell or barter their farm produce, NTFPs, handicrafts, traditional ware, musical instruments and etc. Tamu is also one of the tourist attractions. The main objective of this study was to identify the types of NTFPs collected and traded by the indigenous communities at the various tamu in Sabah, Malaysia.

\section{Materials \& Methods}

Sabah, the second largest Malaysian state, has a land area of 7.3 million ha and a population of 2.45 million (Sabah Statistics Dept. 2000). The main indigenous communities are Kadazandusun, Murut, Rungus and Bajau. There are more than 50 ethnic groups in Sabah (Lasimbang and Moo-Tan 1997). The Kadazandusuns alone comprise more than 30 different groups (Tombung 1990). Other groups in Sabah include the Chinese, Bruneians and Indians.

The general approach of this study is to survey indigenous communities involved in the collection and selling of NTFPs at the selected tати using a structured questionnaire. In each $t a m u$, personal interviews were conducted with the sellers and the data gathered were analyzed to determine the types of NTFPs traded in the tamu. The survey was conducted in ten tamu, namely Tamu Kudat $\left(6^{0} 52.794^{\prime} \mathrm{N}, 116^{0} 51.128^{\prime} \mathrm{E}\right)$, Tamu Kota Marudu $\left(6^{0} 29.925^{\prime} \mathrm{N}, 116^{0} 46.224^{\prime} \mathrm{E}\right)$, Tamu Tandek $\quad\left(6^{0} 32.083^{\prime} \mathrm{N}, 116^{0} 51.197^{\prime} \mathrm{E}\right), \quad$ Tamu Tenom $\quad\left(5^{0} 07.268^{\prime} \mathrm{N}, 115^{0} \quad 56.580^{\prime} \mathrm{E}\right), \quad$ Tamu Keningau $\left(5^{0} 20.333^{\prime} \mathrm{N}, 116^{0} 09.551^{\prime} \mathrm{E}\right)$, Tamu Tambunan $\left(5^{0} 40.250^{\prime} \mathrm{N}, 116^{0} 21.858^{\prime} \mathrm{E}\right)$, Tamu Kiulu $\left(6^{0} 03.527^{\prime} \mathrm{N}, 116^{0} 16.912^{\prime} \mathrm{E}\right)$, Tamu Tamparuli $\left(6^{0} 08.043^{\prime} \mathrm{N}, 116^{0} 16.097^{\prime} \mathrm{E}\right)$, Tamu Telipok $\left(6^{0} 05.372^{`} \mathrm{~N}, 116^{0} 11.740^{\prime} \mathrm{E}\right)$ and Tamu Donggonggon $\left(5^{\circ}\right.$ $\left.54.757^{\prime} \mathrm{N}, 116^{0} 06.085^{\prime} \mathrm{E}\right)$ (Fig 1).

A personal interview technique was used to collect desired information such as respondent background (this covers age, gender, races, education level, household and employment) and inventory of NTFPs traded by the respondent (this covers species, uses, price, sources, distance traveled). For big tamu, random survey was conducted with each seller of NTFPs and for small tamu a 100 percent survey was conducted with each seller of NTFPs. The survey was conducted during weekday and weekend, in the month of September until November 2004. In cases where the NTFPs were not identified in the field, they were bought and brought to the Forest Research Centre (FRC), Sepilok, Sandakan, where the specimens were identified by the botanists of the centre. This was to ensure that all the species collected and sold in the tamu were correctly identified.

\section{Results and Discussion}

The total number of respondent interviewed was 102 respondents, comprising 8 males and 94 females. The majority of the respondents were the Kadazan/Dusun ethnic group, followed by the Rungus and the Murut. The average age of the respondents was 46 years. Most of the NTFPs resources came from the forest with the average distance travelled of 2.1 kilometer by the indigenous traders from their house to the source.

From the surveys, the NTFPs were categorized into eight groups, namely, wild edible plants, medicinal plants, orchids, bamboos, rattans, fish, wild fruit trees and others (Table 1). The most common category of NTFPs traded in the tamu were wild edible plants ( 32.1 percent) and medicinal plants (29.4 percent).

The composition of various NTFPs species found traded in the tamu shows in Table 2. The total number of NTFPs species identified were 109 species, comprising 35 species of wild edible plants, 32 species of medicinal plants, 8 species of orchids, 4 species of bamboos, 6 species of rattans, 8 species of fish, 8 species of wild fruit trees and 8 species of others.

During the surveys, it were also observed that the most expensive NTFPs was Buah Mentayang (Caesalpinia bonduc) followed by Jerangau Merah or Akar Bumi (Baesenbergia stenophylla) and Lumut Gunung (Usnea sp.). All of these species belong to medicinal plants group of NTFPs. In addition, the most frequent of wild edible plants identified were Bungar (Lasia spinosa), Daun Sirih Hutan (Piper betle), Lamiding (Stenochlyna palustris), Pakis (Cylosorus contiguous), Tuhau (Etlingera punicea) and Tutan (Solanum sp.). The surveys also found that the most common species of orchid traded at the tamu ground was Dendrobium sp..

\section{Acknowledgements}

The authors would like to express our sincere gratitude and thanks to the Herbarium Cestion (Mr. John Sugau, Mr. Leopald Madani, Mr. Dewol Sundaling and staffs) of the Sepilok Forest Research Centre for their assistance in identification of the NTFP species, and to Mr. Azman Mahali, Mr. Matin Tuyok, Mr. M.A. Tajjudin Mustapha and Mr. Kasman Kasbi for their invaluable assistances in the interview of the local traders, and to Associate Professor Dr. Awang Abd. Ghani (Faculty of Forestry, Universiti Putra Malaysia) for his invaluable guidance and constructive comments. 


\section{References}

Azizol, A.K. and Appanah, S. (1998). Research and development on the economic benefits of non-timber forest product in Malaysia. (In) Mohd. Yaakub, J., Maryati, M. \& Mary, S.(eds.), proceedings of the seminar and workshop. Sustainable use of forest resources: The prospects of Non-Timber Forest Products (NTFPs) in Sabah. 4-5 May 1998, Kota Kinabalu, Sabah. Pp.1-11.

De Beer, J. and McDermott, M.J. (1989). The economic volume of non-timber forest products in Southeast Asia. Netherlands Committee for IUCN, Amsterdam.

Dransfield, J. (1984). The rattans of Sabah. Sabah Forest Records No. 13. Sabah Forestry Department, Sandakan. 182 pp

Kulip, J. (1992). Survey of bamboo resource and its present status of utilizations in Sabah. Unpublished. Sabah Forestry Department, Sandakan.

Kulip, J. (1997). A preliminary survey of traditional medicinal plants in the West Coast and interior of Sabah. Journal of Tropical Forest Science 10(2): 271-274.

Lasimbang, R. and Moo-Tan, S. (1997). An introduction to the traditional costumes of Sabah. Kota Kinabalu: Natural History Publications. $115 \mathrm{pp}$.

Lee, Y.F. and Gibot, A. (1986). Indigenous edible plants of Sabah. FRC Publication No. 25. Sabah Forestry Department, Sandakan, Sabah. 9 pp.

Sabah Statistics Dept. (2000). Buku laporan perangkaan kiraan permulaan banci tahun 2000. Jabatan Perangkaan Malaysia Cawangan Sabah.

Tiwari, D.D. (1994). Developing and sustaining non-timber forest products: Policy issues and concerns with special reference to India. Journal of World Forest Resource Management 7: 51-78.

Tombung, R.B. (1990). Keluarga Dusun. Sabah, Persatuan Dusun Sabah Bersatu.

Wong, K.M. (1992). Rafflesias, anyone? Sabah's plant life: a new look at a priceless wonder. (In) The environmentthe future is in our hands. Intan Junior Chamber, Sabah. Pp. 26-30.

Table 1. Number of species of traded Non-timber forest products (NTFP's) in the tamu

\begin{tabular}{|c|l|c|c|}
\hline No. & \multicolumn{1}{|c|}{ Categories of NTFPs } & No. of species & Percent (\%) \\
\hline 1 & Wild edible plants & 35 & 32.1 \\
\hline 2 & Medicinal plants & 32 & 29.4 \\
\hline 3 & Orchids & 4 & 3.3 \\
\hline 4 & Bamboos & 6 & 5.5 \\
\hline 5 & Rattans & 8 & 7.3 \\
\hline 6 & Fish & 8 & 7.3 \\
\hline 7 & Wild fruit trees & 8 & 7.3 \\
\hline 8 & Others & 109 & 100.00 \\
\hline
\end{tabular}


Table 2. List of traded Non-timber forest products (NTFP's) found in the tamu

\section{a) Medicinal plants}

\begin{tabular}{|c|c|c|c|}
\hline No. & NTFPs sale (Local name) & Scientific Name & Family \\
\hline 1 & Akar Bumi/Jarangau Merah & Baesenbergia stenophylla & Zingiberaceae \\
\hline 2 & Akar Mengkudu & Morinda citrifolia & Rubiaceae \\
\hline 3 & Akar Petai & Parkia sp. & Leguminosae \\
\hline 4 & Bawang Hutan & Scorodocarpus borneensis & Olaceae \\
\hline 5 & Binuang & Octomeles sumatrana & Datiscaceae \\
\hline 6 & Buah Mentayang & Caesalpinia bonduc & Leguminosae \\
\hline 7 & Dundurok & Rhodomyrtus tomentosa & Myrtaceae \\
\hline 8 & Gangon & Artabotrys roseus & Annonaceae \\
\hline 9 & Gingor & Spatholobus sp. & Leguminosae \\
\hline 10 & Ginseng & Renellia borneensis & Rubiaceae \\
\hline 11 & Kayu Panas & Goniothalamus roseus & Annonaceae \\
\hline 12 & Kokos & Dichapetalum gelonioides & Diclapetalaceae \\
\hline 13 & Kosob/Pinang & Areca catechu & Palmae \\
\hline 14 & Kulat Merah & Polystictus sanguineus & Polyporaceae \\
\hline 15 & Lalamba & (na) & (na) \\
\hline 16 & Lautan Seribu & Gnetum sp. & Guetaceae \\
\hline 17 & Lautan Seribu & Smilax sp. & Smilaceae \\
\hline 18 & Lingzi & Ganoderma sp. & (na) \\
\hline 19 & Lumut Gunung & Usnea sp. & (na) \\
\hline 20 & Pako & Angiopteris sp. & Marattiaceae \\
\hline 21 & Pakodita & Alphitonia excelsa & Rhamnaceae \\
\hline 22 & Raja Kayu & Koompassia malaccensis & Leguminosae \\
\hline 23 & Remunduk & Tetrastigma $\mathrm{sp}$. & Vitaceae \\
\hline 24 & Rosok & Syzygium sp. & Myrtaceae \\
\hline 25 & Sapang & Caesalpinia sappan & Leguminosae \\
\hline 26 & Sikat & Bauhinia sp. & Leguminosae \\
\hline 27 & Sungkang Seribu & Diospyros foxworthyi & Ebenaceae \\
\hline 28 & Tampan Kuning & Tetracera akara & Dilleniaceae \\
\hline 29 & Tampan Merah & Xylocarpus granatum & Meliaceae \\
\hline 30 & Tapako & Drynaria sp. & Polypodiaceae \\
\hline 31 & Tapurau & Enicosanthum sp. & Annonaceae \\
\hline 32 & Tongkat Ali & Eurycoma longifolia & Simaroubaceae \\
\hline
\end{tabular}

na $=$ not available 
b) Wild edible plants

\begin{tabular}{|c|c|c|c|}
\hline No. & NTFPs sale (Local name) & Scientific Name & Family \\
\hline 1 & Bunga Kantan & Eugenia aromatica & Myrtaceae \\
\hline 2 & Bunga Keladi Hutan & Alocasia sp. & Araceae \\
\hline 3 & Bungar Tanggara/Gungguripa & Lasia spinosa & (na) \\
\hline 4 & Cendawan/Kulat Dilah & Polystictus xanthopus & Polyporaceae \\
\hline 5 & Daun Sirih Hutan & Piper betle & Piperaceae \\
\hline 6 & Bukaruk & Schismatoglottis ahmadi & Araceae \\
\hline 7 & Garungang & Goniothalamus sp. & Annonaceae \\
\hline 8 & Halia Merah & Zingiber sp. & Zingiberaceae \\
\hline 9 & Hohombih & (na) & (na) \\
\hline 10 & Kakatung & Limnocharis flava & Limnocharithaceae \\
\hline 11 & Kemangi & Oscimum basilicum & Lamiaceae \\
\hline 12 & Komburiong & Pouzolzia sp. & Urticaceae \\
\hline 13 & Kulat Kodop/Batang & Lentinus sajor-caju & Polyporaceae \\
\hline 14 & Kulat Galanut & (na) & (na) \\
\hline 15 & Kunsui & (na) & (na) \\
\hline 16 & Kuyo & Piper umbellatum & Piperaceae \\
\hline 17 & Lamiding & Stenochlyna palustris & Blechiaceae \\
\hline 18 & Lapak & Physalis minima & Solanaceae \\
\hline 19 & Limposu & Baccaurea lanceolata & Euphorbiaceae \\
\hline 20 & Molopook & Opilia sp. & Opiliaceae \\
\hline 21 & Pakis & Cylosorus contiguus & Thelypteridaceae \\
\hline 22 & Peria Hutan & Momordica sp. & Cucurbitaceae \\
\hline 23 & Polod & Arenga undulatifolium & Palmae \\
\hline 24 & Sang Ngob Tuan & Cucumis sp. & Cucurbitaceae \\
\hline 25 & Sayur Pahit Kampung/Impipiton & Solanum sp. & Solanaceae \\
\hline 26 & Sunsulak & Alocasia sp. & Araceae \\
\hline 27 & Taraan/Ayaan & Monochoria elata & Pontederiaceae \\
\hline 28 & Terung Hutan & Solanum torvum & Solanaceae \\
\hline 29 & Terung Kampung & Solanum sp. & Solanaceae \\
\hline 30 & Terung Pipit & Solanum sp. & Solanaceae \\
\hline 31 & Tongkat Langit/Sesangah & Helminthostachys zeylanica & Ophioglossaceae \\
\hline 32 & Tuhau & Etlingera punicea & Zingiberaceae \\
\hline 33 & Tutan Hijau & Solanum sp. & Solanaceae \\
\hline 34 & Tutan Hitam & Solanum sp. & Solanaceae \\
\hline 35 & Wegang/Ular-ularan & Armorphophyllus pendulus & Araceae \\
\hline
\end{tabular}

na $=$ not available 
c) Orchids

\begin{tabular}{|c|l|l|}
\hline No. & NTFPs sale (Scientific Name) & Family \\
\hline 1 & Dendrobium sp. & Orchidaceae \\
\hline 2 & Phalaenopsis amabilis & Orchidaceae \\
\hline 3 & Aerides sp. & Orchidaceae \\
\hline 4 & Bulbophyllum mandibulare & Orchidaceae \\
\hline 5 & Phaius sp. & Orchidaceae \\
\hline 6 & Kingidium sp. & Orchidaceae \\
\hline 7 & Coelogyne sp. & Orchidaceae \\
\hline 8 & Renanthera bella & Orchidaceae \\
\hline
\end{tabular}

d) Bamboos

\begin{tabular}{|c|l|l|l|}
\hline No. & NTFPs sale (Local name) & Scientific Name & Family \\
\hline 1 & Rebung Nipis & Schizostachyum brachycladum & Gramineae \\
\hline 2 & Rebung Poring & Gigantochloa levis & Gramineae \\
\hline 3 & Rebung Tambalang & Bambusa vulgaris & Gramineae \\
\hline 4 & Rebung Tongkungon & Bambusa blumeana & Gramineae \\
\hline
\end{tabular}

\section{e) Rattans}

\begin{tabular}{|c|l|l|l|}
\hline No. & NTFPs sale (Local name) & Scientific Name & Family \\
\hline 1 & Rotan Lempinit/Lasun & Calamus ornatus & Palmae \\
\hline 2 & Rotan Lesas & Korthalsia hispida & Palmae \\
\hline 3 & Rotan Logong & Calamus acuminatus & Palmae \\
\hline 4 & Rotan Menempun & Calamus levigatum & Palmae \\
\hline 5 & Rotan Saga & Calamus caesius & Palmae \\
\hline 6 & Rotan Tambarua(Umbut) & Plectocomiopsis geminiflora & Palmae \\
\hline
\end{tabular}

\section{f) Wild fruit trees}

\begin{tabular}{|c|l|l|l|}
\hline No. & NTFPs sale (Local name) & Scientific Name & Family \\
\hline 1 & Buah Kamansi & Artocarpus komendo & Moraceae \\
\hline 2 & Buah Keras & Aleurites mollucana & Euphorbiaceae \\
\hline 3 & Buah Panggi & Pangium edule & Flacourtiaceae \\
\hline 4 & Buah Rambai/Kampod & Baccaurea motleyana & Euphorbiaceae \\
\hline 5 & Durian Hutan/Sukang & Durio oxleyanus & Bombacaceae \\
\hline 6 & Takob Akob & Garcina parviflora & Guttiferae \\
\hline 7 & Lampun Belanda & Annona muricata & Annonaceae \\
\hline 8 & Mapiu & (na) & (na) \\
\hline
\end{tabular}

na $=$ not available 
g) Fish

\begin{tabular}{|c|l|l|l|}
\hline No. & NTFPs sale (Local name) & Scientific Name & Family \\
\hline 1 & Ikan Belut & Monopterus albus & Synbranchidae \\
\hline 2 & Ikan Haruan/Jalak & Ophicephalus melanosoma & Ophicephalidae \\
\hline 3 & Ikan Karuk & Anabas testudineus & Anabantidae \\
\hline 4 & Ikan Keli & Clarias sp. & Clariidae \\
\hline 5 & Ikan Selap & Puntius bramoides & Cyprinidae \\
\hline 6 & Ikan Sepat Kampung & Trichogaster trichopterus & Anabantidae \\
\hline 7 & Ikan Sepat Siam & Trichogaster sp. & Anabantidae \\
\hline 8 & Ikan Talapia & Tilapia sp. & Cichlidae \\
\hline
\end{tabular}

h) Others

\begin{tabular}{|c|l|l|l|}
\hline No. & NTFPs sale (Local name) & Scientific Name & Family \\
\hline 1 & Burung Keruak & Amaurornis phoenicurus & Rallidae \\
\hline 2 & Daun Irik & Phacelophrynium maximum & Marantte \\
\hline 3 & Labi-labi & Amaurornis phoenicurus & $(\mathrm{na})$ \\
\hline 4 & Lokan Kogis/bakau & Geloina coaxans & $(\mathrm{na})$ \\
\hline 5 & Madu lebah ${ }^{1}$ & - & - \\
\hline 6 & Siput Sungai/Singor & Terebra sp. & $(\mathrm{na})$ \\
\hline 7 & Rebung Nibong & Oncosperma horridum & Palmae \\
\hline 8 & Umbut Luba/Tiwak & Eugeissonia utilis & Palmae \\
\hline
\end{tabular}

na $=$ not available, ${ }^{1}=$ honey

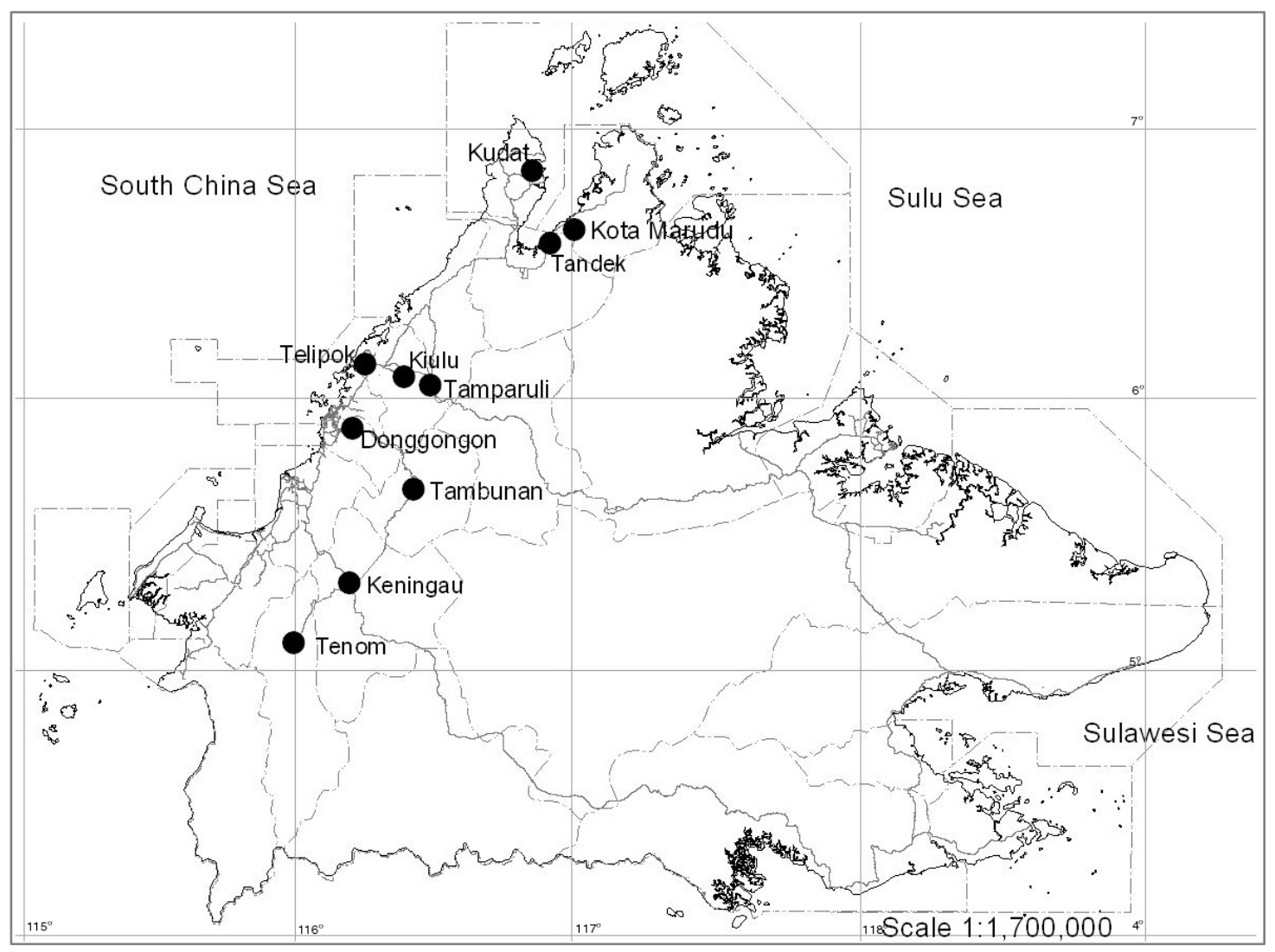

Figure 1. Distribution of locations of the NTFPs survey of ten selected tamu in Sabah

This figure shows the location of ten selected Tamu in this survey 